\title{
SURAN DI TENGAH PAGEBLUG: DAMPAK COVID-19 TERHADAP TRADISI JAWA PADA MASA ADAPTASI KEBIASAAN BARU
}

\section{SURAN IN THE MIDST OF PAGEBLUG: THE IMPACT OF COVID-19 ON JAVANESE TRADITION IN THE NEW NORMAL ERA}

\author{
Adi Putra Surya Wardhana ${ }^{1}$, Fiqih Aisyatul Farokhah ${ }^{2}$ \\ ${ }^{1}$ Universitas Sebelas Maret Surakarta \\ Jalan Ir. Sutami 36A, Kentingan, Surakarta, Jawa Tengah, Indonesia \\ ${ }^{2}$ Institut Agama Islam Tarbiyatut Tholabah Lamongan \\ Jalan Deandles 01, Kranji, Paciran, Lamongan, Jawa Timur, Indonesia
}

Email: adiputra.48697@gmail.com

DOI: 10.36424/jpsb.v7i1.211

Naskah Diterima: 31 Agustus 2020 Naskah Direvisi: 02 Maret 2021 Naskah Disetujui: 03 Maret 2021

\begin{abstract}
Abstrak
Penelitian ini bertujuan untuk mengkaji dampak pageblug Covid-19 terhadap tradisi Suran pada masa Adaptasi kebiasaan baru. Suran berasal dari kata Sura, yaitu bulan pertama dalam sistem penanggalan yang dibuat oleh Sultan Agung. Suran adalah tradisi perayaan pergantian tahun Jawa. Namun, perayaan ini terganggu dengan datangnya pageblug Covid-19. Ada beberapa permasalahan yang dibahas dalam penelitian ini. Pertama, penelitian membahas mengenai asal usul Sura dalam sistem penanggalan Jawa yang dikeramatkan oleh orang Jawa. Kedua, penelitian membahas bentuk tradisi Suran di lingkungan pusat kekuasaan Jawa dan beberapa daerah pedalaman. Ketiga, penelitian membahas tentang dampak Covid-19 terhadap perubahan tradisi Suran di Jawa khususnya pusat kebudayaan Jawa, yaitu istana. Penelitian ini menggunakan metode analisis data kualitatif. Studi kepustakaan digunakan untuk mengumpulkan data tentang pelaksanaan Suran pada masa adaptasi kebiasaan baru. Tradisi Suran di pusat kebudayaan Jawa mengalami perubahan karena harus mematuhi kebijakan pemerintah dan protokol kesehatan. Tradisi Suran di beberapa daerah juga dilaksanakan sesuai protokol kesehatan. Namun demikian, makna tradisi Suran tidak mengalami perubahan, yaitu laku prihatin dan mawas diri demi memperoleh keselamatan.
\end{abstract}

Kata Kunci:TradisiSuran, pageblug,Covid-19, adaptasi kebiasaan baru 


\begin{abstract}
This study analyzes the impact of the Covid-19 pandemic on the Suran tradition during the New Normal era. Suran comes from the word sura, i.e the first month in the Javanese calendar system created by Sultan Agung. Suran is the tradition to celebrate the Javanese New Year. However, this celebration was disrupted bythe Covid-19 pandemic. There are several problems in this study. First, the research discusses the origin of the Sura in the Javanese calendar system which is sacred by the Javanese. Second, the research discusses the form of the Suran tradition in the Javanese power center and some hinterland areas. Third, the research discusses the impact of Covid-19 on changes. Within the Suran tradition in Java, especially the Javanese cultural center, the palace. This study uses qualitative data analysis methods. The Suran tradition at the center of Javanese culture changed because it had to comply with government policies and health protocols. However, the meaning of the Suran tradition has not changed, i.e. the practice of being concerned and introspective to obtain salvation.
\end{abstract}

Keywords: Suran tradition, pandemic, Covid-19, new normal

\title{
PENDAHULUAN
}

Tradisi Suran atau peringatan satu Sura selalu menarik untuk dikaji. Beberapa penelitian mengkaji makna tradisi Suran, hubungannya dengan dakwah Islam, dan persepsi terhadap tradisi Suran (Anis, 2014; Fadlan et al., 2020; Safera \& Huda, 2020; Dani \& Chotijah, 2019; Safitri et al., 2019). Ada pula yang membandingkan tradisi Suran antara keraton dengan daerah pedalaman lainnya (Nurshodiq 2012). Namun, belum ada yang membahas perubahan tradisi Suran yang disebabkan oleh pageblug (wabah) khususnya berkaitan dengan pandemi Covid-19.

Suran merupakan tradisi orang Jawa untuk menyambut tahun baru Jawa yang dilaksanakan dengan upacara-upacara slametan. Tradisi Suran dapat disebut sebagai tanggap warsa yang berarti menyambut kedatangan tahun yang baru, yaitu tahun baru Jawa dan Islam (Anis 2014). Satu Sura merupakan tanggal pertama dalam sistem penanggalan Jawa.

Sura ialah nama bulan dalam kalender Jawa yang dibuat oleh Sultan Agung berdasarkan perayaan Asyura dalam tradisi Islam (Syiah dan Sunni). Bulan Sura menjadi penanda penyesuaian sistem kalender Saka-Hindu yang berdasarkan peredaran matahari dengan kalender Hijriah-Islam yang 
berdasar pada peredaran bulan. Perubahan sistem kalender ini menandai Islamisasi Jawa sekaligus pribumisasi Islam.

Bagi orang Jawa, pergantian tahun merupakan hal yang sakral. Bulan Sura bagi orang Jawa merupakan bulan yang suci dan penuh rahmat. Pergantian tahun dianggap sebagai waktu bertemunya dunia gaib dan dunia manusia dalam kosmologi orang Jawa. Oleh sebab itu, pergantian tahun Jawa merupakan saat yang tepat untuk mempersiapkan diri baik secara spiritual maupun mental agar menjadi pribadi yang lebih baik di tahun yang baru. Bulan Sura menjadi waktu yang tepat bagi orang Jawa untuk manekung dan melakukan laku maladihening atau mendekatkan diri dengan Tuhan Yang Maha Esa (Giri 2010, 53).

Tradisi Suran sudah dilakukan orang Jawa sejak zaman Mataram Islam masa pemerintahan Sultan Agung. Seiring dengan berjalannya waktu, tradisi ini mengalami perubahan-perubahan khususnya di jantung kekuasaan Jawa. Pada masa Sultan Agung, Suran dirayakan dengan menyepi. Setelah perjanjian Giyanti dan Jatisari, sebuah perjanjian yang memberikan sebagian wilayah Paku Buwana III kepada Pangeran Mangkubumi pada 1755, masingmasing otoritas tradisional (Surakarta dan Yogyakarta) ingin membangun identitas kultural masing-masing. Oleh sebab itu, Surakarta dan Yogyakarta memiliki tradisi yang berbeda, termasuk dalam perayaan Suran.

Keraton Kasunanan merayakan Suran dengan kirab kerbau Bule yang diikuti kirab pusaka keraton. Kasultanan Yogyakarta melaksanakan mubeng beteng dengan mengarak panji Kyai Tunggul Wulung. Kadipaten Mangkunegaran merayakan Sura dengan kirab pusaka. Kesamaan dari ketiga kirab adalah pelaksanaan tapa bisu (pantang berbicara). Pelaksanaannya dilakukan dengan berjalan kaki tanpa bersuara satu kata pun selama kirab berlangsung.

Setiap tradisi tidak menutup diri dari perubahan, apalagi jika terjadi kondisi-kondisi tertentu. Salah satu kondisi yang dapat memengaruhi perubahan tradisi atau pun budaya adalah perubahan zaman atau pun kebijakan pemangku otoritas. Contohnya, pada 2015, pelaksanaan kirab 
pusaka Satu Sura antara Pura Mangkunegaran dengan Keraton Kasunanan Surakarta berbeda. Pura Mangkunegaran mengacu pada penetapan pemerintah Republik Indonesia sedangkan Keraton Kasunanan Surakarta mengacu pada sistem kalender yang dibuat oleh Sultan Agung. Artinya, Pura Mangkunegaran menyesuaikan dengan kebijakan pemerintah yang berdaulat, sementara Keraton Kasunanan masih memegang teguh tradisionalitasnya.

"Kami ini hanya pelaksana event tradisional milik publik. Karena itu kami menyesuaikan dengan penetapan penanggalan yang dilakukan oleh Pemerintah. Pemerintah telah menetapkan bahwa 14 Oktober tahun ini adalah 1 Muharam atau 1 Suro maka kirab pusaka malam 1Suro diadakan malam ini. Dengan demikian maka akan memudahkan bagi bagi dan keluarga besar istana untuk berkumpul membuat peringatan bersama," kata KRMT Lilik Tirtodiningrat (Budi 2015).

Kondisi berikutnya yang memengaruhi perubahan ialah pageblug. Pageblug yang menyerang salah satu pusat kekuasaan Jawa, Kesultanan Yogyakarta, memengaruhi timbulnya tradisi baru, yaitu perarakan bendera keramat Kyai Tunggul Wulung pada malam satu Sura. Bendera ini dianggap bertuah karena berasal dari kain yang digantung di makam Nabi Muhammad atau juga berasal dari kiswah Ka'bah. Setiap pageblug, panji Kyai Tunggul Wulung selalu dikirab. Misalnya saja pageblug yang terjadi pada sekitar 1918, yaitu wabah Flu Spanyol. Moertono mencatat kirab yang menyertakan panji-panji Kanjeng Kyai Tunggul Wulung terjadi pada 1932 dan 1948. Tujuannya adalah menyebarluaskan keyakinan bahwa raja sudah memulihkan ketertiban dan digdaya secara kosmologis melawan pageblug (Moertono, 2017: 54-55).

Pada 2020, sebuah pageblug besar terjadi. Covid-19 menyerang seluruh penjuru dunia, termasuk Indonesia. Pageblug ini berawal dari kasus infeksi virus Korona pada akhir 2019 di Provinsi Huben, Cina. Virus ini memiliki kemiripan dengan sindrom pernafasan akut (SARS). Virus ini juga memiliki kedekatan dengan virus korona sindrom Timur Tengah (MERS) yang mewabah di Timur Tengah pada 2012. Namun demikian, karakter virus yang dimiliki berbeda sehingga disebut sebagai SARS-CoV-2 sebagai 
penyebab Covid-19 (Amelia 2020). Pageblug ini membuat terjadinya revolusi kebudayaan yang mendorong era disrupsi untuk bergerak lebih cepat.

Salah satu yang terkena imbas pageblug adalah budaya komunal yang memiliki ikatan solidaritas kuat, yaitu kebudayaan Jawa. Pandemi ini membatasi perjumpaan fisik. Segala kegiatan kebudayaan yang mengumpulkan massa pun harus beradaptasi dengan kebiasaan baru (new normal). Tradisi Suran yang jatuh pada tanggal 21 Agustus 2020 turut terkena dampak dari pandemi Covid-19. Tradisi ini turut terkena dampak karena biasanya selalu mengundang keramaian orang-orang yang ingin mencari berkah (ngalap berkah). Artinya, pandemi atau pageblug memaksa tradisi ini untuk berubah. Itulah sebabnya ada beberapa hal yang ingin dikupas dalam penelitian ini.

Pertama, penelitian membahas mengenai asal usul Sura dalam sistem penanggalan Jawa yang dikeramatkan oleh orang Jawa. Kedua, penelitian membahas bentuk tradisi Suran di lingkungan pusat kekuasaan Jawa dan beberapa daerah pedalaman. Ketiga, penelitian membahas tentang dampak Covid-19 terhadap perubahan tradisi Suran di Jawa khususnya pusat kebudayaan Jawa, yaitu istana. Tujuan penelitian ini adalah mengkaji dampak pageblug Covid-19 terhadap tradisi Suran di Jawa pada masa adaptasi lingkungan baru (New Normal).

Penelitian ini menggunakan pendekatan teori kebudayaan, yaitu perubahan budaya untuk menganalisis perubahan tradisi yang terjadi akibat pageblug Covid-19. Berdasarkan teori tersebut, kebudayaan senantiasa mengalami perubahan atau bersifat dinamis (Setiadi 2008, 44). Perubahan budaya dipengaruhi oleh hubungan kausal variabel-variabel tertentu. Suatu kegiatan disebut sebagai fungsional jika memberi andil bagi adaptasi atau penyesuaian sistem tertentu (Kaplan dan Manners 2012, 82). Perubahan budaya dapat terjadi untuk beradaptasi dengan perubahan lingkungan alam (Setiadi 2008, 44). Penyesuaian manusia terhadap lingkungan dapat dikaji menggunakan teori ekologi budaya. 
Menurut Julian Steward, ekologi budaya berusaha untuk memastikan penyesuaian (adaptasi) manusia terhadap lingkungannya menggunakan mode perilaku tertentu (Steward 2016, 12). Tujuannya adalah agar dapat mengkaji hubungan antara kebudayaan dengan lingkungannya dalam periode tertentu. Dalam kasus ini, lingkungan dipengaruhi oleh pageblug Covid-19. Manusia diharuskan untuk menyesuaikan dengan lingkungan yang diakibatkan oleh Covid-19. Oleh sebab itu, penyesuai ini dikenal dengan istilah adaptasi kebiasaan baru. Adaptasi kebiasaan baru mesti dilakukan oleh masyarakat yang terbiasa melaksanakan tradisi Suran dalam keramaian dan kerumunan. Selain itu, kebijakan pemerintah untuk mengatasi penyebaran Covid-19 melalui pembatasan kegiatan masyarakat pasti memengaruhi perubahan dalam pelaksanaan tradisi Suran.

\section{METODE PENELITIAN}

Penelitian ini menggunakan analisis data kualitatif. Metode analisis data kualitatif digunakan untuk mengkaji masalah ilmu sosial humaniora. Analisis data kualitatif mengulas secara mendalam suatu makna tersembunyi atau disembunyikan melalui interpretasi atau penguraian makna di balik sebuah data (Ratna 2010, 94 \& 306). Analisis data hanya mengkaji sedikit teks. Akan tetapi, metode ini mengkaji teks lebih mendalam. Analisis teks diperlukan untuk mengkaji produksi budaya secara tidak langsung. Caranya adalah dengan membuat deduksi yang spesifik, lokal, atau lebih luas, dan kondisi sosial pada saat produksi budaya berlangsung (Davis 2008).

Studi kepustakaan digunakan sebagai cara untuk mengumpulkan datadata yang dibutuhkan. Data-data yang dimaksud adalah data tentang tradisi Suran pada masa adaptasi kebiasaan baru. Selain itu, penelitian ini menggunakan sumber-sumber artikel ilmiah untuk mendukung narasi ilmiah yang disusun. 


\section{PEMBAHASAN}

\section{Sura sebagai Politik Kebudayaan Sultan Agung}

Pada masa pra Islam, kerajaan-kerajaan di Nusantara menggunakan sistem kalender Saka. Sistempenanggalan ini dimulai pada 15 Maret 78 M. Berdasarkan mitos, sistem penanggalan ini diperkenalkan oleh Raja Ajisaka, seorang tokoh legenda Jawa yang berasal dari India. Ia diyakini sebagai pengkreasi huruf Jawa dan sistem penanggalan yang diadopsi dari India. Dalam sistem penanggalan Saka, ada dua belas bulan dengan jumlah hari total 366 hari. Tahun Saka menggunakan perhitungan solar atau peredaran matahari sehingga sesuai jika dikonversi dalam kalender Masehi yang juga menggunakan perhitungan peredaran matahari (Kamajaya 1985, 221). Berikut nama-nama bulan dalam penanggalan Saka dan konversi dalam kalender Masehi.

Tabel 1. Nama-Nama Bulan Kalender Saka dan Konversinya Dalam Kalender Masehi

\begin{tabular}{|l|l|l|c|}
\hline NO & \multicolumn{1}{|c|}{ Nama } & \multicolumn{1}{c|}{ Konversi } & Jumlah Hari \\
\hline 1 & Srawana & 12 Juli - 12 Agustus & 32 \\
\hline 2 & Bhadra & 13 Agustus - 10 September & 29 \\
\hline 3 & Asuji & 11 September - 11 Oktober & 31 \\
\hline 4 & Kartika & 12 Oktober - 10 November & 30 \\
\hline 5 & Posya & 11 November - 12 Desember & 32 \\
\hline 6 & Margasirsa & 13 Desember - 10 Januarei & 29 \\
\hline 7 & Magha & 11 Januari - 11 Februari & 32 \\
\hline 8 & Phalguna & 12 Februari - 11 Maret & 29 \\
\hline 9 & Cetra & 12 Maret- 11 April & 31 \\
\hline 10 & Wsakha & 12 April - 11 Mei & 30 \\
\hline 11 & Jyesta & 12 Mei - 12 Juni & 32 \\
\hline 12 & Asadha & 13 Juni - 11 Juli & 29 \\
\hline \multicolumn{2}{|c|}{ Total } & 366 \\
\hline
\end{tabular}

Sumber: (Azhari dan Ibrahim 2008, 133)

Setelah kerajaan Hindu-Buddha runtuh, kalender Saka masih digunakan oleh kerajaan-kerajaan Islam. Kalender Saka digunakan bersamasama Kalender Hijriah oleh Kesultanan Demak, Banten, dan Mataram Islam. Kalender Saka masih digunakan hingga awal abad XVII. Tahun-tahun awal Sultan Agung memerintah Mataram, sistem kalender yang digunakan masih 
sistem penanggalan Hindu Saka. Sistem kalender tersebut digunakan untuk memperingati upacara-upacara kerajaan yang sakral (Ricklefs 2008, 109).

Pada masa itu, penduduk Mataram (Islam) masih dipengaruhi oleh sistem kepercayaan Hindu, Budha, dan kepercayaan lokal. Alih-alih memulai sistem kalendernya dari titik nol, Sultan Agung memutuskan untuk melanjutkan tahun Saka. Caranya adalah dengan melanjutkan bilangan tahun Saka sebagai titik awal perhitungan kalender dengan umur bulan mengacu pada sistem perhitungan Kalender Hijriah. Kala itu, Sultan Agung menetapkan kebijakan kalender pada 1555 Saka yang bertepatan pada $1043 \mathrm{H}$ atau 1633 M. Selisih antara tahun Saka dan Hijriah ialah 512 tahun (Lombard 2005, 237).

Dalam kalender Jawa, perhitungan hari dibagi menjadi mingguan yang terdiri dari tujuh hari dan sepasaran yang terdiri dari lima hari. Penanggalan Jawa juga menggunakan siklus windu (delapan tahunan). Seluruh nama bulan pada kalender Saka diubah menggunakan bahasa Arab yang disesuaikan dengan lidah Jawa agar sesuai dengan kalender Hijriah, yaitu Sura, Sapar, Mulud, Bakdamulud, Jumadilawal, Jumadilakhir, Rejeb, Ruwah, Pasa, Sawal, Selo, dan Besar. Nama-nama hari pun diubah menggunakan nama hari dalam kalender Islam, yaitu Ahad, Senin, Selasa, Rebo, Kemis, Jumuah, dan Sebtu.

Tabel 2. Nama-nama bulan Kalender Hijriah

\begin{tabular}{|l|l|l|l|l|l|}
\hline No & Nama & Panjang Hari & No & Nama & Panjang Hari \\
\hline 1 & Muharram & 30 hari & 2 & Safar & 29 hari \\
\hline 3 & R. Awal & 30 hari & 4 & R. akhir & 29 hari \\
\hline 5 & Jumadilawal & 30 hari & 6 & Jumadilakhir & 29 hari \\
\hline 7 & Rajab & 30 hari & 8 & Syakban & 29 hari \\
\hline 9 & Ramadan & 30 hari & 10 & Syawal & 29 hari \\
\hline 11 & Zulkaidah & 30 hari & 12 & Zulhijah & $29 / 30$ hari \\
\hline
\end{tabular}

Sumber: (Azhari dan Ibrahim 2008) 
Dalam kalender ciptaan Sultan Agung, terdapat beberapa ketentuan. Pertama, Satu Sura tahun Alip 1555 A.J. jatuh pada hari Jumat Legi tanggal 1 Muharram $1043 \mathrm{H}$ atau 8 Juli 1633 M. Kedua, satu periode memerlukan waktu delapan tahun (windu). Ketiga, satu windu terdiri dari tiga tahun panjang/ wuntu (355 hari) dan lima tahun pendek/ wastu (354 hari). Keempat, pada bulan gasal memiliki umur 30 hari, sedangkan bulan genap berumur 29 hari (kecuali bulan Besar pada tahun Wuntu ditambah satu hari sehingga menjadi genap 30 hari). Kelima, hari pasaran dalam kalender Saka tetap dipertahankan (Legi, Pahing, Pon, Wage, Kliwon). Terakhir, pergantian kurup dilakukan setiap 120 tahun (Azhari dan Ibrahim 2008).

Perayaan-perayaan besar yang berhubungan dengan tradisi Hindu diubah agar sesuai dengan perayaan Islam. Misalnya saja perayaan Mulud dalam tradisi Islam yang menggantikan perayaan Phalguna-Caitra dalam tradisi pra Islam. Perayaan lebaran menggantikan perayaan Rajapatni (Lombard 2005). Sejak itu, sistem penanggalan ini disebarluaskan oleh Sultan Agung sebagai salah satu bentuk Islamisasi di wilayah Mataram Islam. Namun demikian, sistem penanggalan Jawa dan Hijriah memiliki perbedaan sehingga bisa saja pergantian tahun antara kedua kalender tersebut jatuh pada hari yang berbeda.

Persoalan sejarah sistem penanggalan tercatat dalam sebuah naskah Jawa, yaitu Serat Widya Pradhana. Naskah ini ditulis oleh Ranggawarsita pada 1913. Naskah ini merupakan koleksi Sasana Pustaka Kasunanan Surakarta. Dalam katalog yang dibuat Florida, naskah ini memiliki nomor 16 Ca SMP 158/9.

Mênggah gancaripun Sêrat Widya Pradhana wau nyariyosakên lampahing palak. Amung dipunpêndhêt awit saking pangetangipun taun Syamsiah kalihan taun Kamariah kemawon. Têgêsipun taun srêngenge kalihan taun rêmbulan. Kasêbut wontên salêbêting kitab Wasilatultulab sapanunggilanipun.

Dene ingkang dados bêbuka etanging taun kalih pisan wau sami amendhêt tuturutan saking lampahing cakraning Surya Candra. Têgêsipun mênawi etanging taun srêngenge nurut 
lampahipun cakraning Surya, mênawi etanging taun rêmbulan inggih nurut lampahing cakraning Candra. Ing mangsa kalanipun sami gumiling mangidul mangalèr...(Ranggawarsita 1913).

Sehubungan dengan Serat Widya Pradhana tadi menceritakan perjalanan falak. Diambil sejak dari perhitungan tahun Syamsiah dan tahun Qomariah saja. Artinya tahun matahari dan tahun bulan. Disebutkan di dalam Kitab Wasilatultulab dan sejenisnya.

Pembukaan, hitungan kedua tahun tersebut diambil secara berurutan dari perjalanan perputaran matahari dan bulan. Artinya seumpama perhitungan tahun matahari menurut jalannya perputaran matahari. Jika perhitungan tahun bulan berdasarkan peredaran bulan.

Sebagai pembukaan, hitungan kedua tahun tersebut mengambil dari jalannya perputaran matahari dan bulan. Artinya jika hitungan tahun matahari menurut jalannya perputaran matahari. Jika hitungan tahun bulan menurut perputaran bulan. Jika sudah musimnya saling berputar ke selatan ke utara.

Berdasarkan petikan naskah tersebut, Ranggawarsita menjelaskan dua jenis sistem penanggalan, yaitu berdasarkan peredaran matahari dan peredaran bulan. Ranggawarsita lantas menjelaskan perhitungan-perhitungan sistem penanggalan berdasarkan peredaran matahari dan bulan. Ia menerangkan, bangsa Arab pun pernah menggunakan sistem penanggalan beradarkan matahari pada masa Sultan Kahtan dengan titik awal yaitu munculnya Nabi Ismail. Baru pada masa Nabi Muhammad, sistem penanggalan diubah menjadi berdasarkan bulan dengan perhitungan hisab maupun rukyat. Dalam penanggalan bulan dikenal tahun Wastu atau tahun pendek dan tahun Wuntu atau tahun kabisat.

Orang Jawa menggunakan perhitungan Hijriah, tetapi digabungkan dengan sistem pasaran Jawa yang terdiri dari Pon, Wage, Kliwon, Legi, dan Pahing.

Ing mangke amratelakakên awitipun wulan taun Arab kangge wontên ing tanah Jawi. Nalika taun Ijrah 931, amarêngi ing taun Surya Sangkala 1400. Kaetang ing taun Candra Sangkala Jawi 1443 jaman nagari ing Demak. Panganggitipun Sunan Giri kaping II lampahing 
pananggalan kaugêran saking kurup Alip, He, Jim, Je, Dal, Be, Wawu, Jim (Ranggawarsita 1913).

Kemudian diceritakan awal digunakannya tahun Arab di tanah Jawa. Saat tahun Hijriah 931 bersamaan dengan tahun Surya 1400. Dihitung pada tahun bulan Jawa 1443 zaman Demak. Yang mengarang adalah Sunan Giri II proses penanggalan diatur kurup Alip, He, Jim, Je, Dal, Be, Wawu, Jim.

Petikan naskah tersebut menunjukkan bahwa penggunaan kalender Hijriah yang disesuaikan dengan penanggalan Saka sudah dilakukan oleh Sunan Giri II. Ranggawarsita sama sekali tidak menyebut nama Sultan Agung. Artinya, pernyataan Ranggawarsita dalam karyanya tersebut seolah menyanggah klaim yang menyatakan bahwa penanggalan Jawa diciptakan oleh Sultan Agung. Agaknya, hal ini berkaitan dengan konflik antara Sultan Agung dengan Giri Kedhaton. Sekitar 1636, Sultan Agung menyerang Giri Kedhaton melalui Pangeran Pekik Surabaya (Ricklefs 2008).

Apakah Ranggawarsita memiliki simpati kepada keturunan Sunan Giri yang ditundukkan oleh Sultan Agung? Perlu diketahui bahwa Ranggawarsita merupakan seorang cendekiawan, ulama, dan pujangga sekaligus. Ia pernah nyantri di Pondok Pesantren Tegalsari. Ranggawarsita mungkin ingin mengukuhkan sistem penanggalan Jawa sebagai warisan dari Sunan Giri II sebagai trah salah seorang Wali Sanga, bukannya Sultan Agung. Wali Sanga memiliki pengaruh besar bagi masyarakat Islam Jawa sebagai tokoh suci. Oleh sebab itu, hal ini bisa dipahami jika Ranggawarsita menyebut asal usul penanggalan Jawa sebagai warisan trah tokoh suci Islam di Jawa. Pernyataan Ranggawarsita digunakan untuk legitimasi penggunaan kalender tersebut di lingkungan keraton karena memiliki sanad dari seorang Wali yang suci.

Soal tidak disebutkannya Sultan Agung, agaknya hal tersebut merupakan kritik intern atas penaklukan trah Giri Kedhaton. Kala itu, pasukan Mataram dan Surabaya juga berat hati dalam menyerang Giri Kedhaton yang dipimpin oleh seorang suci. Penaklukan tersebut mengakhiri kekuasaan seorang Wali. Penaklukan tersebut melegitimasi Sultan Agung 
sebagai satu-satunya penguasa Islam yang berkuasa di bumi Jawa. Boleh jadi, penaklukan Sultan Agung atas Giri Kedhaton dianggap sebagai tindakan amoral.

Sementara itu, menurut R. Tanaya dalam Kabudayan Paugeraning Taun Jawa (1971), sistem penanggalan Jawa merupakan warisan Sultan Agung sebagai berikut.

Barêng tumêka jaman Karaton Jawa Islam ing Mataram, ing sajumênêng dalêm Sri Sultan Agung Prabu Anyakrakusuma, ana kêparênging karsa nata yasa paugêraning taun Jawa, awêwaton taun Kamariyah, iya iku taun miturut petungan rêmbulan, kang bisa nyakup antarane kabudayan Jawa, Hindhu lan Arab, kaya ta:

1. Panyakupe kabudayan Jawa: anggone bisa mêngku dina lan pasaran kang bisa tumbuk sabên sawindu, sarta bisa mêngku pawukon kang bisa tumbuk sabên rong windu, tuwin bisa mêngku masa wuku kang bisa tumbuk sabên patang windu.

2. Panyakupe kabudayan Hindhu: anggone nglêstarèkake tumindake angkaning taun Saka 1555 kang maune awêwaton taun Syamsiyah, banjur kadadèkake angkaning taun Jawa 1555 kang awêwaton taun Kamariyah.

3. Panyakupe kabudayan Arab: anggone migunakake wêwaton taun Kamariyah, nganggo sasi 12 miturut aran lan tatananing sasine taun Arab, kang wigati tumrap kanggo nindakake prêluning agama Islam (Tanaya 1971).

Setelah mencapai zaman Keraton Jawa Mataram, pada saat Sultan Agung Hanyakrakusuma berkehendak untuk membuat tahun Jawa, asal usul Qomariyah, yaitu tahun berdasaran perhitungan bulan, yang bisa menjembatani kebudayaan Jawa, Hindu, dan Arab, seperti:

1. Mencakup kebudayaan Jawa: cara agar dapat melestarikan hari dan pasaran agar dapat bertepatan setiap satu windu, dan bisa merawat pawukon yang dapat bertepatan setiap dua windu, dan juga bisa mencakup masa wuku yang dapat bertepatan setiap empat windu.

2. Mencakup kebudayaan Hindu: cara melestarikan angka tahun Saka 1555 yang mulanya berdasarkan dari tahun Syamsiah, lalu dijadikan angka tahun Jawa 1555 yang berdasarkan dari tahun Qomariah.

3. Mencakup kebudayaan Arab: tentang penggunaan berdasarkan tahun Qomariah, menggunakan dua belas bulan berdasarkan nama dan tata bulan tahun Arab yang bertujuan untuk melaksanakan syariat agama Islam. 
Dalam tulisannya tersebut, R. Tanaya menegaskan bahwa sistem penanggalan Jawa ditetapkan oleh Sultan Agung. Menurutnya, penanggalan Jawa menyatukan kebudayaan Jawa, Hindu, dan Arab. Oleh sebab itu, Sultan Agung dianggap sebagai seorang penguasa Islam yang berkharisma karena dapat menyatukan perbedaan-perbedaan tersebut. Tulisan Tanaya jelas bertentangan dengan karya Ranggawarsita. Perbedaan ini bukan hal yang mengherankan dalam khasanah intelektual Jawa karena berkaitan dengan sumber, metodologi, dan politik kebudayaan.

Pengaruh politik tidak dapat dilepaskan dari penciptaan sebuah karya, termasuk klaim pencetus sistem penanggalan Jawa. Klaim Sultan Agung sebagai pencetus sistem penanggalan Jawa merupakan bagian dari politik kebudayaan. Motivasi tindakannya adalah untuk mengukuhkan kekuasaan sebagai seorang penguasa sekaligus pemimpin agama Islam tertinggi di Jawa. Politik kebudayaan melalui sistem penanggalan dibangun paskaa kekalahan Sultan Agung atas usaha penaklukan Batavia. Sultan Agung juga gagal menguasai seluruh Jawa. Itulah sebabnya setiap pergantian tahun dilakukan dengan rasa prihatin, penyepian, dan mawas diri oleh Sultan Agung. Artinya, pergantian tahun merupakan masa yang tepat untuk mengenang kekalahan dan kesalahan di masa lalu agar dapat mencapai kemenangan atas batin.

Pada pergantian tahun, pusaka-pusaka yang dimiliki kerajaan dibersihkan dengan ritual yang sakral. Pusaka-pusaka bertuah dikeluarkan sebagai simbol kekuasaan raja. Ada pantangan-pantangan tertentu yang harus ditaati selama bulan Sura. Rakyat pun takut dengan sanksi-sanksi gaib yang bisa saja menimpa. Sultan Agung membangun diskursus kegaiban malam satu Sura untuk konsolidasi kekuasaan dan penundukan rakyat. Melalui sistem penanggalan Jawa, Sultan Agung membangun hegemoni dan dominasi. Oleh sebab itu, Sultan Agung selalu dikenang sebagai raja yang besar.

\section{Perayaan Tradisi Suran}

Tradisi Suran merupakan tradisi besar. Tradisi besar merupakan 
tradisi yang dibangun di lingkungan kerajaan. Artinya, tradisi besar merupakan konstruksi yang dibangun oleh penguasa Jawa. Tentu saja konstruksi budaya yang dibangun untuk kepentingan penguasa, yaitu memperoleh hegemoni dan legitimasi. Konstruksi ini terus menyebar di berbagai lapisan masyarakat yang masih memiliki ikatan dengan pusat kekuasaan Jawa. Dalam hal ini, daerah-daerah yang dimaksud adalah wilayah kekuasaan Kerajaan Mataram Islam.

Kasunanan Surakarta sebagai kerajaan hasil pembagian Kerajaan Mataram pasca perjanjian Giyanti pada 1745 melaksanan tradisi Suran dengan kirab Kebo Bule. Kerbau albino tersebut merupakan pemberian bupati Ponorogo saat Paku Buwana II mengungsi akibat geger Pacinan yang meluluhlantakkan ibu kota Mataram Kartasura. Kerbau ini disebut sebagai Kyai Slamet (Imamah 2017, 91). Sejak Kerajaan Mataram Kartasura boyong kedhaton ke Surakarta, Kerbau Kyai Slamet menjadi hewan klangenan Paku Buwana II.

Kerbau albino dipercaya sebagai hadiah Kyai Hasan Beshari Tegalsari Ponorogo. Pisungsun tersebut dimaksudkan sebagai cucuk lampah (pengawal) dari pusaka bernama Kyai Slamet (Sajid 1984). Mitosnya, pemilihan lokasi istana baru pasca rusaknya Keraton Kartasura melibatkan Kebo Bule. Kerbau-kerbau itu dilepas begitu saja dengan diikuti dengan para abdi dalem. Tempat kerbau-kerbau tersebut berhenti dijadikan patokan lokasi istana yang baru (Perpustakaan Nasional 2017).

Satu Sura dirayakan oleh Keraton Kasunanan dengan mencuci pusaka kerajaan dengan sakral. Perayaan dimulai dengan jamasan pusaka. Pusakapusaka yang dibersihkan dan disucikan tidak melulu berwujud senjata (tombak, keris, pedang). Alat-alat musik istana (gamelan) juga turut di-jamas. Jamasan dimaksudkan agar kekuatan gaib yang ada di dalamnya dapat memberikan pengaruh positif bagi kerajaan. Upacara jamasan dilakukan dengan ritus yang kompleks. Ada pembacaan mantra, doa-doa permohonan, dan pencucian dengan air suci yang dicampur dengan bunga-bunga bermakna suci juga (Imamah 2017). 
Setelah itu, pada tengah malam mendekati dini hari, kerbau-kerbau albino dikirab. Kirab dilakukan dengan mengelilingi tembok Keraton Kasunanan Surakarta. Namun, kerbau-kerbau itulah yang menentukan rute kirab. Abdi dalem yang membawa pusaka keraton hanya mengikuti kerbaukerbau tersebut. Daya magis kerbau-kerbau ini dipercayai masyarakat Surakarta dapat membawa keberkahan. Oleh sebab itu, ribuan orang selalu datang untuk mengambil segala yang dijatuhkan kerbau Kyai Slamet tersebut termasuk kotorannya. Laku kirab dilakukan dengan tapa bisu atau tidak boleh mengucapkan satu patah katapun. Tradisi Suran yang diadakan oleh keraton bertahan hingga masa Republik Indonesia.

Tradisi Suran bukan monopoli istana. Masyarakat yang tinggal di luar tembok istana pun turut merayakan Suran. Hanya saja, tradisi Suran setiap daerah tersebut tidak seragam. Masing-masing daerah memiliki kekhasan dalam perayaan tradisi Suran. Daerah-daerah di luar wilayah kebudayaan keraton juga memiliki tradisi Suran-nya masing-masing. Tradisi Suran yang dilakukan masyarakat pedesaan termasuk dalam tradisi kecil.

Dalam penelitian yang dilakukan Fadlan et al., (2020), masyarakat Bangungharjo Desa Tamansari merayakan Suran dengan menyembelih kambing. Kurban tersebut disembelih untuk menghindari malapetaka dan musibah. Menurutnya, tradisi Suran di daerah ini dilakukan setelah datangnya pageblug yang menyerang masyarakat Bangunharjo. Pageblug tersebut berupa epidemi penyakit kulit yang menyerang masyarakat Bangunharjo. Setelah dilaksanakan kurban kambing, pageblug mereda.

Selain kurban, Suran dilakukan dengan upacara riungan. Maksud upacara riungan adalah sebagai bentuk ucapan syukur terhadap Tuhan yang telah memberikan anugerah kehidupan, keselamatan, dan kesejahteraan. Upacara berikutnya adalah pertunjukan wayang kulit. Pertunjukan diadakan selepas upacara riungan pada malam hari. Pertunjukan wayang dilakukan semalam suntuk.

Sementara itu, tradisi Suran di wilayah Kabupaten Wonosobo dilakukan dengan bersih-bersih desa, membersihkan wangon, dan 
membersihkan saluran irigasi. Masyarakat desa menggelar upacara ritual berupa pemanggilan roh Kyai Semar melalui seorang mediator tokoh spiritual yang dihormati di desa. Masyarakat desa melakukan laku prihatin dengan berpuasa ngebleng (puasa tanpa makan dan minum sama sekali), ngrowot (puasa tanpa makan nasi atau beras), bertapa, dan berdoa kepada Tuhan Yang Maha Kuasa. Masyarakat berusaha menjaga keseimbangan dan keselarasan alam sebagai cara untuk menghormati para tokoh yang menjadi cikal bakal daerah Wonosobo (Nurshodiq 2012).

Perayaan Suran dimeriahkan dengan pementasan Lengger (pertunjukan kesenian tari rakyat) dengan lakon kisah panji pukul 21.00 WIB hingga 4.00 WIB. Lengger berasal dari kata le yang berarti laki-laki dan ngger yang bermakna geger (heboh). Bisa juga berasal dari kata eling (ingat) dan ngger (panggilan untuk anak laki-laki). Pada pagi harinya, kesenian kuda kepang dipertunjukkan. Ziarah dilakukan ke makam Adipati Mertoloyo dan makam sesepuh desa. Beragam jajanan dan makanan dipersiapkan untuk diperebutkan masyarakat. Upacara dilanjutkan dengan Selametan. Setelah itu, pada malam harinya diadakan pentas wayang kulit semalam suntuk (Nurshodiq 2012).

Demikianlah keragaman tradisi Suran yang dilakukan di beberapa daerah. Keragaman tradisi Suran dapat dicatat sebagai berikut.

1. Wungon, begadang sepanjang malam.

2. Andon Lampah, berjalan-jalan menuju tempat yang sepi, berkunjung ke tempat-tempat sakral, gunung, pantai, pesisir, laut, danau, telaga, jeram, gua, dan sebagainya.

3. Renungan, secara kelompok atau individual introspeksi diri dengan bertapa, berdiam diri, berhening diri, dan sebagainya.

4. Larungan, mengadakan sesaji di tempat-tempat sakral seperti puncak gunung, pantai, laut, telaga, gua, petilasan, dan sebagainya.

5. Tirakatan, laku pengendalian diri dengan berpuasa, berpantang, dan sebagainya.

6. Slametan, kenduri, atau wilujengan dilakukan dengan menggelar 
selamatan yang dilakukan pada tanggal 8 atau pada hari Jumat bulan tersebut.

7. Kidungan dilakukan dengan mengkaji wewarah atau petunjuk, wiridan, kajian serat atau primbon tentang keselamatan.

8. Bawarasa dilakukan dengan menggelar sarasehan, temu rasa, dan menukar wawasan.

9. Sesuci dilakukan dengan membersihkan diri, jamasan, membersihkan pusaka leluhur, membersihkan lingkungan, dan sebagainya.

10. Sujarahan dilakukan dengan berziarah ke makam leluhur atau pepundhen desa.

11. Pagelaran dilaksanakan dengan menggelar tontonan bermuatan tuntunan seperti wayang kulit, wayang golek, rebana, dan sebagainya.

12. Siaga diri, kirab pusaka, kirab perangkat keselamatan, dsb (Bratasiswara 2000, 12-13).

\section{Perayaan $n$ Masa Adaptasi Kebiasaan Baru}

Corona Virus Diseas 2019 (COVID-19) adalah nama virus yang menyebabkan pandemi di seluruh belahan dunia. Virus ini mulai dideteksi pada Desember 2019 di Wuhan, Provinsi Hubei, Tiongkok. Virus ini segera menyebar dengan cepat ke seluruh Cina dan beberapa negara hanya dalam waktu satu bulan sejak pertama kali dilaporkan. Pada Feburari 2020, jumlah infeksi mencapai 44.653 kasus dan jumlah kematian mencapai 1.113 di Tiongkok (Hui et al. 2020, 243).

Jumlah infeksi terus meningkat seiring dengan peningkatan jumlah rapid test dan swab test. Pandemi ini memengaruhi segala sektor kehidupan mulai dari sosial, ekonomi, budaya, dan psikologi. Peneliti menganggap, pandemi ini memiliki daya kerusakan yang mirip dengan epidemi influenza dunia (Flu Spanyol) pada 1918 (Jahangir, Muheem, dan Rizvi 2020, 1).

Pada Februari 2020, Menteri-menteri Pemerintah Republik Indonesia berusaha untuk meyakinkan rakyat bahwa pandemi belum menyebar ke Indonesia. Menteri Perhubungan, Budi Karya, bercanda bahwa Indonesia 
tidak terinfeksi korona karena masyarakat gemar memakan nasi kucing (Hakim 2020). Tidak lama berselang, kasus pertama akhirnya dipublikasikan, yaitu pada awal Maret 2020.

Secara kronologis, kasus pertama yang dideteksi berasal dari seorang pasien yang bekerja dengan WNA Jepnng. Pasien ini mengadakan kontak dengan WNA Jepang tersebut pada 14 Februari 2020. Pada 28 Februari, WNA Jepang yang pernah kontak dengan pasien tersebut dinyatakan positif Covid-19. Pasien tersebut juga dinyatakan positif oleh Rumah Sakit (Nuraini 2020). Pasca penemuan kasus pertama, klaster-klaster Covid-19 terus muncul dengan peningkatan yang cukup drastis di berbagai wilayah di Indonesia. Pemerintah pun mengambil kebijakan untuk melakukan pembatasan sosial. Protokol kesehatan menjadi diskursus yang terus disebarluaskan guna menangkal penyebaran.

Pageblug Covid-19 tidak berhenti. Rumah-rumah ibadah sempat ditutup, meskipun kemudian dibolehkan untuk dibuka dengan kewajiban menjalankan protokol kesehatan. Hari-hari penting umat beragama dilalui dengan keprihatinan. Umat Muslim dibatasi pergerakannya untuk mudik dan Sholat Ied baik di lapangan terbuka maupun di Masjid. Umat Kristen tidak bisa merayakan Paskah di Gereja. Demikian pula dengan umat Hindu dan Buddha yang tidak bisa beribadah di tempat ibadah untuk merayakan hari besar keagamaannya.

Mendekati pergantian tahun Islam (Muharam) atau Jawa (Sura), Covid-19 masih menjadi ancaman. Kegiatan-kegiatan yang mengumpulkan massa masih dilarang. Umat Islam Jawa pun harus berbesar hati untuk tidak merayakan Suran seperti biasanya. Pura Mangkunegaran sudah sejak 10 Agustus 2020 mengumumkan bahwa kirab pusaka sebagai bagian dari tradisi Suran ditiadakan (Puro Mangkunegaran 2020). Pura Mangkunegaran hanya mengadakan wilujengan (selamatan) dengan peserta yang terbatas. Di Masjid Al-Wustho Mangkunegaran, Semaaan Al-Quran diadakan guna memperingati tahun baru Jawa dan Islam. 


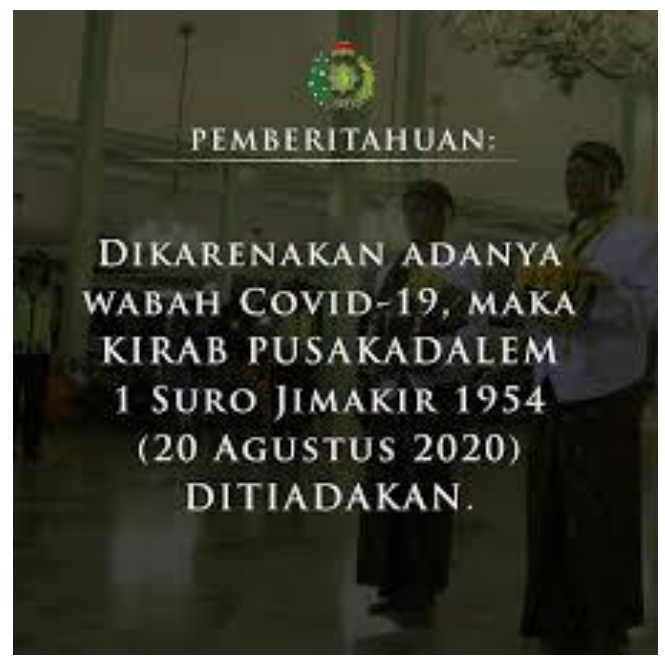

Gambar 1. Pemberitahuan peniadaan Kirab Pusaka Dalem Mangkunegaran (Sumber: Agenda Solo (@agendasolo))

Keraton Surakarta juga mengeluarkan publikasi tentang peniadaan kirab pusaka 1 Sura.

"Kirab pusaka tahun ini ditiadakan karena pandemi, kan rawan sekali kalau berdesak-desakan, tapi kalau upacara adat wilujengan tetap diadakan terbatas dengan protokol kesehatan," kata Wakil Pengageng Sasana Wilapa Keraton Kasunanan Surakarta, KRA Dani Narsugama Adiningrat(detik.com 19 Agustus 2020).

Pernyataan tersebut menunjukkan bahwa pageblug berdampak pada perubahan tradisi. Tradisi Suran Keraton Kasunanan Surakarta adalah kirab pusaka Kyai Slamet yang bertahan selama ratusan tahun sejak Perjanjian Giyanti 1745. Dahulu, tradisi Suran menjadi sarana politik kebudayaan otoritas tradisional. Tradisi Suran selalu dimanfaatkan untuk membangun daya magis dan kharisma seorang penguasa. Ketika otoritas tradisional tidak lagi memiliki kekuasaan politik akibat Penetapan Pemerintah No. 16/SD Tahun 1946 yang disusul peraturan perundangan lain tentang pembentukan Provinsi Jawa Tengah pada 1950, tradisi kirab terus dilaksanakan. Kirab pusaka menjadi ajang penguasa tradisional menunjukkan kekuasaannya dalam hal kebudayaan, yaitu sebagai pengayom kebudayaan Jawa. 


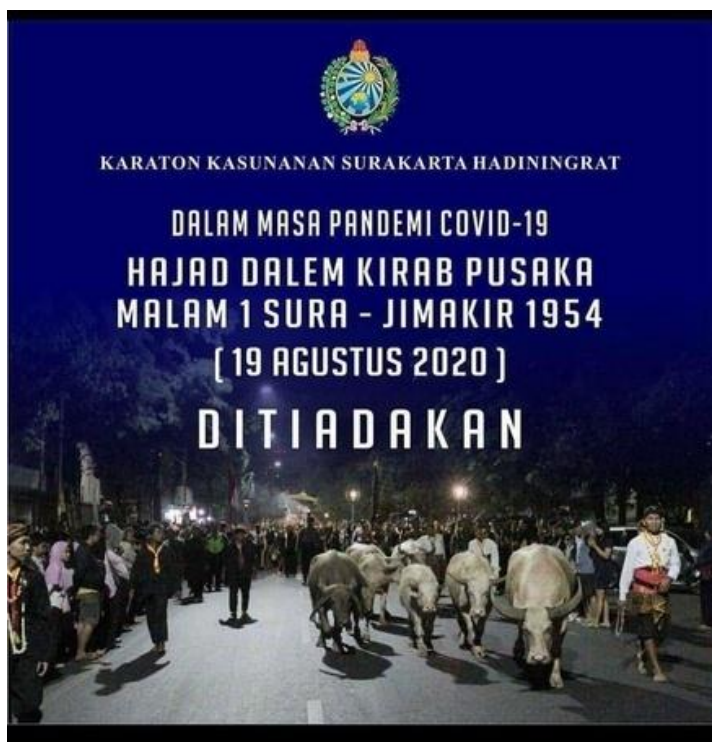

Gambar 2. Pengumuman peniadaan Kirab Pusaka 1 Sura Keraton Kasunanan Surakarta Sumber: (Isha'an 2020)

Covid-19 memaksa istana untuk menghentikan tradisi kirab tersebut. Di masa lalu, kirab bakal tetap dilaksanakan dengan membawa pusakapusaka yang dapat menangkal pageblug. Kepercayaan masyarakat Jawa pada masa lampau menganggap bahwa daya magis pusaka keraton mampu mengusir segala mara bahaya termasuk pageblug. Namun demikian, masa kekinian jelas berbeda. Otoritas pemerintah RI memiliki kekuasaan agar lembaga-lembaga kebudayaan mematuhi kebijakan kesehatan yang ditetapkan. Komunitas keraton pun merayakan tradisi Suran dengan mengadakan upacara wilujengan. Doa-doa dipanjatkan agar pageblug segera berlalu.

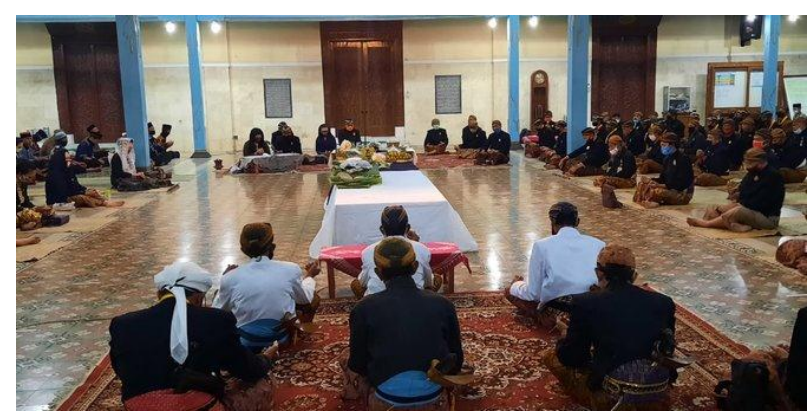

Gambar 3. Wilujengan yang diselenggarakan Keraton Kasunanan Surakarta Sumber: (Sunaryo 2020) 
Wilujengan yang diadakan pun agak berbeda dari wilujengan biasa. Upacara ini dilakukan dengan protokol kesehatan. Setiap individu harus menjaga jarak tertentu dan mengenakan masker. Kontak fisik seperti bersalaman juga tidak boleh dilakukan.

"Kita tetap menggelar acara wilujengan napaki tahun anyar Jimakir 1954. Acara ini diikuti undangan terbatas, dari sentono dalem maupun abdi dalem dengan menerapkan protokol Covid-19," ujar Ketua LDA Keraton Kasunanan Surakarta GKR Koes Moertiyah Wandansari (Sunaryo 2020).

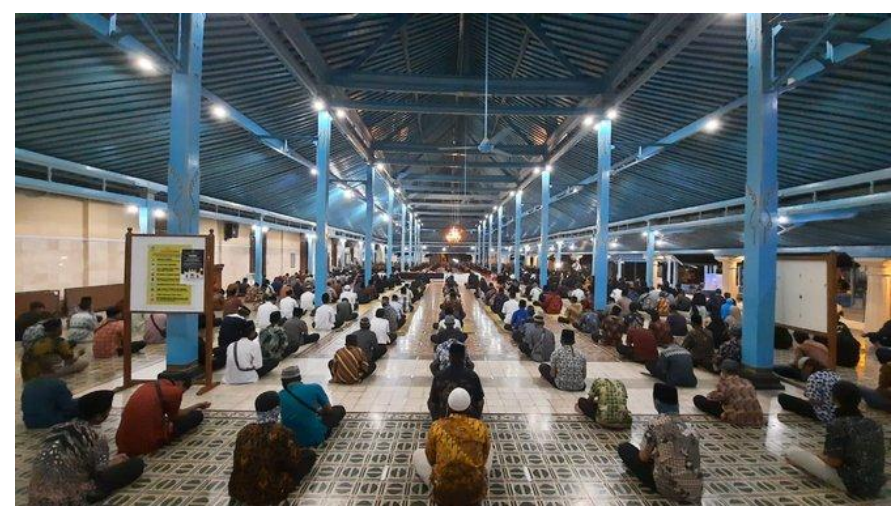

Gambar 4. Nampak jaga jarak fisik sebagai bagian dari protokol kesehatan. Sumber: (Sunaryo 2020)

Upacara wilujengan dilakukan pada pukul 21.00 WIB hingga 22.00 WIB. Waktu wilujengan hanya satu jam atau enam puluh menit. Biasanya, wilujengan dilakukan lebih dari satu jam. Artinya, wilujengan yang diadakan keraton sudah disesuaikan dengan protokol kesehatan agar tidak terlalu lama ketika mengadakan acara yang mengumpulkan massa.

Kegiatan wilujengan diawali dengan tahlil dzikir karena bertepatan dengan peringatan meninggalnya Paku Buwana X. Lalu, wilujengan dilakukan guna meyambut tahun baru Jawa, yaitu tahun Jimakir 1954 A.J. Doa-doa dipanjatkan agar Indonesia segera melalui pageblug Covid-19 dengan selamat. Doa-doa juga dipanjatkan untuk kebaikan keraton dan masa depan Indonesia sebagai peringatan kemerdekaan Indonesia(Sunaryo 2020).

Kasultanan Yogyakarta turut meniadakan tradisi mubeng beteng (Pangaribowo 2020). Pada masa lampau, Sultan mengeluarkan panji Kiai 
Tunggul Wulung untuk dikirab memutari beteng keraton sebagai simbol penghalau pageblug. Kirab Kiai Tunggul Wulung juga menjadi simbol ketaatan rakyat (kawula) terhadap Gustinya (Tuhan). Namun demikian, kirab Kiai Tunggul Wulung tidak dilakukan dalam tradisi Suran pada masa pageblug Covid-19. Sri Sultan memilih untuk menetapkan kebijakan berbasis protokol kesehatan dengan mengingatkan agar setiap orang selalu eling dan waspada. Kegiatan pengganti mubeng beteng adalah gelar doa bersama yang dilakukan di sekitar Bangsal Ponconiti Keraton Yogyakarta pada pukul 21.30 WIB. Upacara ini hanya dilakukan oleh beberapa abdi dalem tanpa mengundang masyarakat.

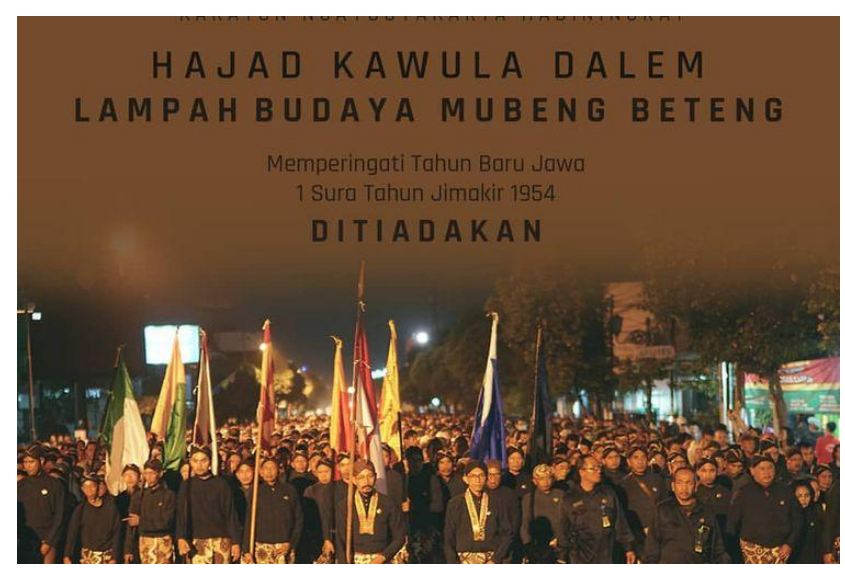

Gambar 5. Pengumuman peniadaan Tradisi Mubeng Beteng Kasultanan Yogyakarta Sumber: Dok Keraton Yogyakarta; Pangaribowo, 2020

Sementara itu, perayaan Satu Sura di kompleks makam Panembahan Senopati, Kotagede, Yogyakarta juga ditiadakan. Biasanya, di kompleks tersebut diadakan upacara tirakatan dan pembagian bubur Sura selepas tahlil. Pada masa pageblug Covid-19, kompleks ini tetap dibukatetapi dibatasi oleh protokol kesehatan (CNN Indonesia 2020). Pengunjung hanya dapat melakukan laku tapa secara pribadi di tempat ini.

Para seniman Jawa di Taman Mini Indonesia Indah merayakan tradisi Suran dengan menggelar seni pertunjukan daring bertajuk "Umbul Dungo Nuswantoro" melalui Youtube. Para seniman TMII juga melakukan umbul dungo agar pageblug Covid-19 segera berlalu. Para seniman tersebut berkeinginan agar masyarakat dapat merayakan Suran dengan penuh khidmat 
di rumah masing-masing. Acara tersebut juga diikuti dengan doa agar Indonesia memperoleh keberkahan dan keselamatan (TMII Official 2020)

Di Desa Traji, Parakan, Temanggung, Jawa Tengah, masyarakat mengadakan tradisi Suran secara terbatas. Biasanya, tradisi Suran di desa ini selalu dihadiri oleh ribuan masyarakat yang datang untuk memperoleh keberkahan dan keselamatan. Pada perayaan di masa pageblug Covid-19, perayaan dihadiri oleh pemangku adat dan puluhan orang saja. Ritual disiarkan secara daring agar masyarakat dapat mengikuti tradisi ini dari rumah (Efizudin 2020).

Di Desa Sumbermujur, Lumajang, Jawa Timur, tradisi Suran dirayakan dengan menggelar Grebeg Suro di objek wisata Hutan Bambu. Hanya saja, pembatasan dilakukan agar sesuai dengan protokol kesehatan. Para panitia, penari, dan tamu undangan diwajibkan mengenakan masker. Grebeg Suradilaksanakan dengan kirab gunungan hasil bumi, kepala sapi, ingkung, dan abu rampen diiringi oleh Tari Oling. Tari pengiring tersebut merupakan simbol belut yang sering menampakan diri di sumber mata air selama upacara penanaman kepala sapi berlangsung (Liputan6.com 21 Agustus 2020).

Hampir seluruh daerah di Jawa merayakan tradisi Suran yang berbeda dengan tradisi yang biasa dilakukan setiap tahun. Pusat kebudayaan Jawa, keraton, meniadakan upacara Suran, tetapi menggantinya dengan wilujengan atau pun tirakatan. Beberapa daerah merayakan secara terbatas karena harus mengikuti protokol kesehatan di era adaptasi kebiasaan baru. Artinya, tradisi Suran benar-benar harus beradaptasi dengan kebiasaan yang baru, yaitu kebiasaan berdasar protokol kesehatan.

Pandemi Covid-19 menjadi variabel-variabel yang memengaruhi perubahan perayaan tradisi Suran di berbagai wilayah Indonesia. Perayaan upacara tradisi Suran yang dilakukan sesuai protokol kesehatan merupakan bagian dari adaptasi sistem tertentu sebagaimana pendapat Kaplan dan Manners. Kegiatan perayaan tradisi Suran pun bisa disebut sebagai fungsional (Kaplan dan Manners 2012). Hanya saja, kefungsionalannya 
bersifat temporer karena menyesuaikan dengan kondisi darurat yang diakibatkan oleh pandemi. Masyarakat percaya bahwa pandemi pasti berakhir sehingga tradisi ini bisa dilaksanakan seperti dahulu.

Perubahan yang terjadi memang masih dalam tahap temporer atau sementara yang terus berproses untuk menemukan bentuk yang sesuai dalam masa adaptasi kebiasaan baru. Oleh sebab itu, setiap daerah melaksanakan tradisi Suran secara berbeda-beda karena berdasarkan pada inisiatif dari pihak penyelenggara yang bersifat darurat (sementara). Namun demikian, bukan tidak mungkin perayaan tradisi Suran berubah secara laten. Bahkan, perubahan bisa terjadi secara terus-menerus apabila virus Covid-19 terus bermutasi, sementara penggunaan vaksin belum merata.

Meskipun tradisi Suran mengalami perubahan, makna dari tradisi ini tidak berubah. Inti dari tradisi sejak masa Sultan Agung adalah keprihatinan. Laku prihatin merupakan sikap hidup asketis masyarakat Jawa guna mencapai tujuan hidup, yaitu manunggaling kawula Gusti. Melalui laku prihatin, setiap insan diharapkan mampu menghayati sangkan paraning dumadi (asal muasal kehidupan). Melalui laku dalam tradisi Suran, setiap manusia Jawa mesti mampu mengendalikan hawa nepsu dan pamrih (egoisme) (Magnis-Suseno 1984, 139).

Dalam laku tapaada malam Satu Sura, setiap individu diajak untuk menata sikap batin yang tepat agar mampu bermawas diri. Dengan demikian, setiap insan mampu memenangkan perang melawan dirinya sendiri, menguasai tubuhnya sendiri, guna mengatur serta membudayakan dorongandorongannya dan bukan meniadakannya. Tapa dapat memperkuat kehendal dalam usaha guna mempertahankan keseimbangan batin dan perbuatan sesuai tuntutan keselarasan sosial (Magnis-Suseno 1984). Dengan demikian, manusia Jawa dapat berlaku sebagai kalifatullah — wakil Tuhan di dunia guna merawat seluruh ciptaan-Nya dan menjaga keharmonisan dengan alam.

\section{PENUTUP}

Sura merupakan nama bulan pertama dalam sistem penanggalan Jawa. 
Sistem penanggalan ini diakui sebagai ciptaan Sultan Agung pasca kegagalan menaklukan Batavia. Sistem penanggalan ini dibuat dalam bingkai politik kebudayaan. Tujuannya adalah membangun hegemoni dan dominasi kekuasaan Sultan Agung sebagai pemimpin negara dan agama tertinggi di wilayah Kerajaan Mataram (Islam).

Tradisi Suran dilakukan dengan bermawas diri seperti yang dilakukan oleh Sultan Agung. Dalam perkembangannya, tradisi Suran di pusat kekuasaan Jawa dilakukan dengan jamasan pusaka, kirab pusaka, dan mubeng beteng. Rangkaian upacara dilakukan dengan khidmat dan sakral. Tradisi Suran di lingkungan pusat kekuasaan Jawa mengandung politik kebudayaan, yaitu membangun hegemoni dan penundukan. Hal ini karena ribuan orang selalu hadir dalam upacara tersebut. Kebanyakan di antara mereka bertujuan untuk ngalap berkah.

Sementara itu, beberapa daerah di Jawa melaksanakan tradisi Surandengan beragam. Keragaman tersebut di antaranya wungon, andon lampah, renungan, larungan, tirakatan, slametan, kenduri, wilujengan, kidungan, bawarasa, sesuci, sujarahan, pagelaran, siaga diri dan kirab gunungan serta pusaka. Tradisi Suran selalu dihadiri oleh ribuan orang untuk ikut merayakan kedatangan tahun yang baru.

Kala pageblug Covid-19 melanda, tradisi Suran mengalami perubahan. Pusat kebudayaan Jawa, istana, meniadakan upacara tradisi yang biasanya selalu diadakan setiap tahun. Istana-istana di Jawa merayakan tradisi Suran dengan wilujengan atau pun tirakatan secara terbatas. Beberapa daerah di Jawa juga merayakan Suran dengan mematuhi protokol kesehatan sebagai bentuk adaptasi fungsional. Beberapa daerah lainnya sama sekali tidak mengadakan tradisi Suran. Penyelenggara menghimbau agar masyarakat Islam Jawa maupun Kejawen merayakan di rumah masing-masing.

Dengan demikian, perayaan Suran masa pageblug ditinjau dari segi ekologi budaya merupakan cara untuk beradaptasi dengan lingkungan yang baru. Masyarakat Jawa yang terbiasa merayakan tradisi secara komunal dipaksa untuk menyendiri dan berjauh-jauhan oleh lingkungan. Dari realitas 
ini dapat dilihat bahwa perubahan budaya sudah terjadi, bahkan masih berlangsung saat penelitian ini dilakukan. Meskipun perubahan yang terjadi masih dalam tahap temporer, makna tradisi Suran masih tetap sama, yaitu bermawas diri agar menjadi insan yang lebih baik agar selalu eling (ingat) dan waspada. Selain itu agar setiap insan menghayati sangkan paraning dumadi(awal mula kehidupan). Kondisi pageblug justru menguatkan makna tradisi Suran agar selalu ingat kepada Sang Pencipta yang berkuasa atas segala misteri kehidupan.

Purna wicara, penelitian ini dapat menjadi pemantik penelitianpenelitian soal tradisi di tengah era adaptasi kebiasaan baru. Apalagi, masyarakat Jawa merupakan masyarakat yang komunal dengan ikatan solidaritas tinggi. Protokol kesehatan yang menjadi inti dari era adaptasi kebiasaan baru tentu memengaruhi tradisi dan budaya Jawa. Oleh sebab itu, menjadi pemantik penelitian-penelitan lain tentang dampak Covid-19 terhadap tradisi-tradisi Jawa lainnya. 


\section{DAFTAR PUSTAKA}

Amelia, Nabila. 2020. "Mengenal Perkembangan Jenis Baru Virus Corona yang Infeksi Ribuan Orang." UNAIR NEWS. http://news.unair.ac.id/2020/01/31/mengenal-perkembangan-jenisbaru-virus-corona-yang-infeksi-ribuan-orang/ (Agustus 15, 2020).

Anis, Madhan. 2014. "Suran: Upacara Tradisional dalam Masyarakat Jawa." Jurnal Seuneubok Lada 2(1): 53-60.

Azhari, Susiknan, dan Ibnor Azli Ibrahim. 2008. "Kalender Jawa Islam: Memadukan Tradisi dan Tuntutan Syar'i." Jurnal Asy-Syir'ah 42(I): 131-47.

Bratasiswara, Harmanto. 2000. Suran Dalam Pembudayaan Waktu Jawa. Jakarta: Pengurus Pusat Himpunan Kerabat Mangkunegaran Suryosumirat.

Budi, Muchus. 2015. "Beda Dasar, Kirab Pusaka Malam Satu Suro di Solo Digelar Beda Waktu." Detik.com. https://news.detik.com/berita/d3043422/beda-dasar-kirab-pusaka-malam-satu-suro-di-solo-digelarbeda-waktu.

CNN Indonesia. 2020. "Sepi Malam 1 Suro Yogya: Nihil Lampah Budaya dan Tirakatan." CNN Indonesia. https://www.cnnindonesia.com/gayahidup/20200820121505-284-537626/sepi-malam-1-suro-yogya-nihillampah-budaya-dan-tirakatan.

Dani, Akhmad Anwar, dan Siti Chotijah. 2019. "Pesan Dakwah Dalam Kirab Budaya Malam 1 Suro Kraton Kasunanan Surakarta." HIKMAH 13(1): 60-74.

Davis, Aeron. 2008. "Investigating Cultural Producers." In Research Methods for Cultural Studies, ed. Michel Pickering. Edinburgh: Edinburgh University Press Ltd, 53-67.

Efizudin, Anis. 2020. "Tradisi malam Satu Suro di tengah pandemi COVID19." ANTARA. https://kalteng.antaranews.com/nasional/berita/1678582/tradisimalam-satu-suro-di-tengah-pandemi-covid19?utm_source=antaranews\&utm_medium=nasional\&utm_campaign =antaranews.

Fadlan, M, Sudjarwo, dan Risma Margaretha Sinaga. 2020. "Social Action in Suroan Tradition in Javanese Society." EUROPEAN ACADEMIC 
RESEARCH VII(11): 5573-88.

Giri, Wahyana. 2010. Sajen \& Ritual Orang Jawa. Yogyakarta: Narasi.

Hakim, Luqman. 2020. "Budi Karya: Virus COVID-19 tidak masuk Indonesia karena "nasi kucing."' antaranews.com. https://www.antaranews.com/berita/1302390/budi-karya-virus-covid19-tidak-masuk-indonesia-karena-nasi-kucing.

Hui, Luo et al. 2020. "Can Chinese Medicine Be Used for Prevention of Corona Virus Disease 2019 (COVID-19)? A Review of Historical Classics, Research Evidence and Current Prevention Programs." Chinese Journal Integrative Medicine 26(4): 243-50. www.cjim.cn/zxyjhen/zxyjhen/ch/index.aspx.

Imamah, Fardan Mahmudatul. 2017. "Seeking for Berkah: the Celebration of Kiai Slamet.” Kawalu: Journal of Local Culture 4(1): 85-106.

Isha'an, Mulato. 2020. "Keraton Surakarta Meniadakan Kirab Kerbau Bule 1 Suro." $\quad$ rri.co.id. https://rri.co.id/surakarta/senibudaya/885297/keraton-surakarta-meniadakan-kirab-kerbau-bule-1suro?utm_source=news_populer_widget\&utm_medium=internal_link \&utm_campaign=General Campaign.

Isnanto, Bayu Ardi. 2020. "Keraton Kasunanan dan Mangkunegaran Solo Tiadakan Kirab Malam 1 Suro." detikNews. https://news.detik.com/berita-jawa-tengah/d-5139247/keratonkasunanan-dan-mangkunegaran-solo-tiadakan-kirab-malam-1-suro.

Jahangir, Mohammed Asadullah, Abdul Muheem, dan Midhat Fatima Rizvi. 2020. "Coronavirus (COVID-19): History, Current Knowledge and Pipeline Medications." International Journal of Pharmaceutics \& Pharmacology 4(1).

Kamajaya, Karkono. 1985. Kebudayaan Jawa Perpadan dengan Islam. Yogyakarta: Ikatan Penerbit Indonesia Cabang Yogyakarta.

Kaplan, David, dan Albert A. Manners. 2012. Teori Budaya. Yogyakarta: Pustaka Pelajar.

Liputan6.com. 2020. "Menjaga Tradisi Grebeg Suro di Tengah Pandemi COVID-19." Liputan6.com. https://surabaya.liputan6.com/read/4336008/menjaga-tradisi-grebegsuro-di-tengah-pandemi-covid-19.

Lombard, D. 2005. Nusa Jawa Silang Budaya Bagian II: Jaringan Asia. 
Jakarta: Gramedia Pustaka Utama.

Magnis-Suseno, Frans. 1984. Etika Jawa. Jakarta: PT. Gramedia.

Nuraini, Tantiya Nimas. 2020. "Kronologi Munculnya Covid-19 di Indonesia hingga Terbit Keppres Darurat Kesehatan." Merdeka.com. https://www.merdeka.com/trending/kronologi-munculnya-covid-19di-indonesia-hingga-terbit-keppres-darurat-kesehatan-kln.html.

Nurshodiq. 2012. "Tradisi Suran dalam Masyarakat Jawa (Studi Perbandingan antara Wilayah Surakarta dengan Wonosobo).” Journal of Educational Social Studies 1(1): 55-59. http://journal.unnes.ac.id/sju/index.php/jess.

Pangaribowo, Wisang Seto. 2020. "Patuhi Imbauan Pemerintah, Keraton Yogyakarta Tiadakan Tradisi Mubeng Beteng di Malam 1 Suro." Kompas.com.

https://yogyakarta.kompas.com/read/2020/08/19/13574321/patuhi-imbauanpemerintah-keraton-yogyakarta-tiadakan-tradisi-mubeng-beteng.

Perpustakaan Nasional. 2017. "Sejarah Kerbau Kyai Slamet salah satu Pusaka Keraton Kasunanan Surakarta." perpusnas.go.id. http://keraton.perpusnas.go.id/node/261 (Agustus 15, 2020).

Puro Mangkunegaran. 2020. "Puro Mangkunegaran Kirab Pusakadalem 1 Suro Jimakir 1954 Ditiadakan." Puro Mangkunegaran. https://puromangkunegaran.com/kirab-pusakadalem-1-suro-jimakir1954-ditiadakan/.

Ranggawarsita. 1913. Serat Widya Pradhana. Surakarta: Sasana Pustaka Kasunanan Surakarta.

Ratna, Nyoman Kutha. 2010. Metodologi Penelitian Kajian Budaya dan Ilmu Sosial Humaniora pada Umumnya. Yogyakarta: Pustaka Pelajar.

Ricklefs, M.C. 2008. Sejarah Indonesia Modern 1200-2008. Jakarta: Serambi.

Safera, Damar, dan Muhammad Chairul Huda. 2020. "Tradisi Suroan sebagai Tapak Tilas Walisongo (Studi di Desa Jatirejo Kecamatan Suruh Kabupaten Semarang)." Al-Mada; Jurnal Agama, Sosial dan Budaya 3(1): 66-79.

Safitri, Dian Puspa, Sohibussafa'ah, dan Arlin Dwi S. 2019. "Persepsi Mahasiswa IAIN Surakarta terhadap Ritual 1 Suro Keraton 
Kasunanan Surakarta." Academica: Journal of Multidisciplinary Studies 3(2): 205-18.

Sajid, RM. 1984. Babad Sala. Surakarta: Reksa Pustaka Mangkunegaran.

Setiadi, Elly M. 2008. Ilmu Sosial dan Budaya Dasar. Jakarta: Kencana Prenada Media Group.

Steward, Julian. 2016. "The Concept and Method of Cultural Ecology." In The Environment in Anthropology (Second Edition): A Reader in Ecology, Culture, and Sustainable Living, ed. Nora Haenn, Richard R. Wilk, dan Allison Harnish. New York: NYU Press, 12-17.

Sunaryo, Arie. 2020. "Sambut Satu Suro, Keraton Surakarta Gelar Wilujengan Doakan Covid-19 Sirna." Merdeka.com. https://www.merdeka.com/peristiwa/.

Tanaya, R. 1971. Kabudayan Paugeraning Taun Jawa: Kang bisa nyakup marang antarane: Kabudayan Jawa Asli, Kabudayan Hindhu lan Kabudayan 'Arab. Pambuka Wewadining Neptu Taun lan Sasi. Surakarta: Yayasan Sastra Lestari.

TMII Official. 2020. "Malam 1 Suro 1954/ 1 Muharram 1442 H.” TMII Official. https://youtu.be/lxbl1bCoqGA (Agustus 19, 2020).

www.instagram.com/agendasolo/ 